doi $10.15826 /$ recon.2021.7.2.007

UDC 332.1

JEL O3 R11

\title{
Measurement of the intellectual capital of Russian regions
}

\author{
N.Sh. Roze
}

Institute of Economics, Finance and Business, Bashkir State University, Ufa, Russia; nelliona@yandex.ru

\begin{abstract}
Relevance. The rapid growth in the value of intangible resources brings up a problem of managing innovative development and evaluating intellectual capital. Intellectual capital is essential for socio-economic development of countries and regions. Research objectives. The key objective of this study is to develop an approach to evaluate the balance of structural components of regional intellectual capital. Data and methods. The proposed approach has been tested on the data from 75 Russian regions for 2000-2018. Calculations are made on the basis of mathematical formulae, the methods of linear scaling and of paired comparisons. Visualization of the calculation results was carried out by using the GeoDA spatial modeling software. Results. The article describes an approach to assessing the balance between the structural components of intellectual capital. It includes a measurement algorithm, a system of indicators and a model for assessing structural components of intellectual capital, a criterion scale for determining the balance of structural components. The proposed approach allows us to develop a step-by-step guide to effective decision-making. Conclusion. The proposed approach and indicators can be used for devising strategies of intellectual capital management on the regional level.
\end{abstract}

\section{KEY WORDS}

intellectual capital, innovative development, assessment of intellectual capital, human capital, structural capital, relational capital

\section{FOR CITATION}

Roze, N.Sh. (2021) Measurement of the intellectual capital of Russian regions.

R-economy, 7(2), 72-87.

doi: $10.15826 /$ recon.2021.7.2.007

\section{Оценка интеллектуального капитала российских регионов}

\author{
H.ШI. Розе
}

Институт экономики, финансов и бизнеса, Башкирский государственный университет, Уфа, Россия; nellliona@yandex.ru

\begin{abstract}
АННОТАЦИЯ
Актуальность. Повышение ценности нематериальных ресурсов ставит проблему управления инновационным развитием и оценки интеллектуального капитала. Интеллектуальный капитал необходим для социально-экономического развития стран и регионов. Цель исследования. Ключевой целью данного исследования является разработка подхода к оценке сбалансированности взаимодействия структурных компонентов интеллектуального капитала региона. Данные и методы. Предлагаемый подход был апробирован на данных 72 регионов России в период с 2000 по 2019 год. Визуализация результатов расчетов произведена с использования программного пакета пространственного моделирования GeoDA. Результаты. В статье описан подход к оценке баланса структурных составляющих интеллектуального капитала. Он включает в себя алгоритм измерения, систему показателей и модель оценки структурных составляющих интеллектуального капитала, шкалу критериев для определения сбалансированности структурных составляющих. Предлагаемый подход позволяет разработать пошаговое руководство по эффективному принятию решений. Выводы. Предлагаемый подход и индикаторы могут быть использованы для разработки стратегий управления интеллектуальным капиталом на региональном уровне.
\end{abstract}

\section{КЛЮЧЕВЫЕ СЛОВА}

интеллектуальный капитал, инновационное развитие, оценка уровня интеллектуального капитала, человеческий капитал, структурный капитал, отношенческий капитал

\section{ДЛЯ ЦИТИРОВАНИЯ}

Roze, N.Sh. (2021) Measurement of the intellectual capital of Russian regions.

R-economy, 7(2), 72-87. doi: $10.15826 /$ recon.2021.7.2.007

\section{Introduction}

Global challenges and trends, the ubiquity of the Internet of Things, the acceleration of the product lifecycle, technological innovation and many other phenomena of the coming digital revolution cause inevitable changes in the systems and economic structure of countries and regions. Innovations transform the social paradigm of people's lives. Companies, regions and countries that have mastered new methods and tools for managing intangible resources get significant economic benefits and may become leaders of change. 
These trends are reflected by the federal strategic documents of the Russian state, such as the "Strategy for Innovative Development of the Russian Federation until 2020", "Strategy for Scientific and Technological Development of the Russian Federation until 2035", the state program "Scientific and Technological Development of the Russian Federation", in particular its sub-program "Development of the National Intellectual Capital". It is reasonable to assume that activities based on science-based approaches and methods, technological process, and managerial innovations are designed to improve the quality of life, labor productivity and human efficiency. However, in order to develop strategies aimed at stimulating innovative development, it is necessary to study the relationships and patterns in the management process to select the most effective tools.

Based on earlier research, this paper divides regional intellectual capital into three components - human, structural and relational capital (Kuzminykh et al., 2019). Human capital refers to the resources of individuals who have all the necessary knowledge and abilities to respond promptly to the changes that constitute innovative development. Structural capital corresponds to the organizational and administrative resources of a region (procedures, technologies, management systems, hard- and software, administrative structure, intellectual property) that contribute to the codification of knowledge. Relational capital is here understood as resources resulting from interactions with internal and external stakeholders in the social, economic, political, and organizational spheres (Roze, 2018).

The key objective of this study is to propose an approach to the evaluation of structural components and to the development of recommendations to improve the effectiveness of intellectual capital management in regions. To achieve this goal, the following tasks need to be addressed:

- to analyze the approaches to the assessment of intellectual capital at the regional level;

- to develop an algorithm for assessing intellectual capital and the balance of its structural components;

- to determine the indicators that characterize each structural component of intellectual capital for calculation of integral indicators of human, structural and relational capital;

- to determine the approach, calculation formula, and criteria for assessing the level of intellectual capital;
- to develop a set of criteria for assessing the balance between the structural components of intellectual capital;

- to test the approach by using the data on Russian regions.

\section{Literature review}

Intellectual capital is the main resource of innovative development in the twenty-first century; it determines the competitiveness and prosperity of territories in their transition to innovation economy. This is what makes evaluation of intellectual capital and systems for its management so important. As far as the structure of intellectual capital on the regional and national levels is concerned, 4 or more components are usually identified (Roze, 2017). For example, A. Rembe identifies 4 components of national intellectual capital: human capital, market capital, process capital, and renewable capital (Rembe, 1999). E. Pasher points out 5 components: financial capital, human capital, market capital, technological capital, renewal and development fund (Pasher 2005). N. Bontis describes five subcategories of national intellectual capital: human capital, capital market, process capital, renewal capital, and financial capital (Bontis, 2004). J. Pomeda et al. argue that national intellectual capital consists of human, organizational, technological, reputational, and social capital (Pomeda, 2002).

G. Tovstig and E. Tulugurov consider regional intellectual capital as the sum of all the enterprises operating on its territory. They also consider external socio-political and economic factors and internal factors such as human and structural capital (Tovstig \& Tulugurov, 2009).

One of the components of intellectual capital on the national and regional level discussed in research literature is renewal capital (Rembe, 1999; Ståhle, 2005; Pasher, 2005; Weziak, 2007; Makarov, 2015), which refers to technology, the ability to develop and support innovation and reproduce intellectual capital. However, if we look at renewal capital as organizational and technical knowledge, this resource can be attributed to structural capital (Roze, 2017).

One of the key features of intellectual capital is the fact that its effectiveness is determined by the interaction of its structural components (Xia \& Niu, 2010; Naydenova \& Oskolkova, 2012; Alkhateeb, Yao, Cheng, 2018; Barilenko, 2019; Maryam, 2021; Pap, Petković, Simićević, 2021). 
Methodologies for evaluation of intellectual capital include the following types:

1) methodologies based on assessment of the intellectual capital of an enterprise (Khuzina, 2015);

2) methodologies based on the calculation of an integral index of intellectual capital or indicators for each of its structural elements;
3) methodologies based on determining quantitative rather than qualitative indicators

Unfortunately, there are no methods for calculating the monetary indicator that could be used to evaluate the intellectual capital of a region.

Table 1 below provides a brief overview of the current approaches to evaluation regional intellectual capital.

Comparative analysis of approaches to the evaluation of intellectual capital

Table 1

\begin{tabular}{|c|c|c|}
\hline Authors / approach & Advantages & Disadvantages \\
\hline 1 & 2 & 3 \\
\hline $\begin{array}{l}\text { Bontis, N. (2004) / National in- } \\
\text { tellectual capital index (Bontis, } \\
\text { 2004) }\end{array}$ & $\begin{array}{l}\text { This approach allows to identify } \\
\text { countries with high rates of national } \\
\text { intellectual capital in relation to their } \\
\text { financial capital }\end{array}$ & $\begin{array}{l}\text { 1. The indicators used for calculating the sub-in- } \\
\text { dices are unbalanced; } \\
\text { 2. subjectivity of weighting in the coefficients } \\
\text { method }\end{array}$ \\
\hline $\begin{array}{l}\text { Tumyan, L.V. (2015) / General- } \\
\text { ized index of national intellec- } \\
\text { tual capital }\end{array}$ & $\begin{array}{l}\text { The methodology is based on the } \\
\text { principle of information accessibility }\end{array}$ & $\begin{array}{l}\text { 1. The use of ratings instead of relative and abso- } \\
\text { lute statistics can lead to inadequate results; } \\
2 \text {. When only one rating is used, the final indica- } \\
\text { tor of the national capital index becomes subjec- } \\
\text { tive and shows a certain research bias. }\end{array}$ \\
\hline $\begin{array}{l}\text { Mačerinskienė, I., Mačer- } \\
\text { inskas, J., Aleknavičiūtè, R. } \\
\text { (2012) / National model for } \\
\text { measuring intellectual capital }\end{array}$ & $\begin{array}{l}\text { The methodology helps determine } \\
\text { the value of national intellectual } \\
\text { capital }\end{array}$ & $\begin{array}{l}\text { The use of the expert method for factor weighting } \\
\text { gives relatively unbiased results only if a large } \\
\text { number of experts are involved. }\end{array}$ \\
\hline $\begin{array}{l}\text { Andriessen, D. (2008) / ICM } \\
\text { model }\end{array}$ & $\begin{array}{l}\text { The methodology helps determine } \\
\text { the relationship between spatial } \\
\text { distribution of intellectual capital and } \\
\text { the development of specific spatial } \\
\text { formations }\end{array}$ & \multirow{2}{*}{$\begin{array}{l}\text { 1. This method does not allow us to assess intel- } \\
\text { lectual capital in terms of value. } \\
\text { 2. The indicators used for comparison can be } \\
\text { applied only in combination with the indicators } \\
\text { of the development of territorial institutions, } \\
\text { industries and individual enterprises. } \\
\text { 3. Unbalanced indicators }\end{array}$} \\
\hline $\begin{array}{l}\text { Chub, A.A. (2015) / Adaptation } \\
\text { of ICM models }\end{array}$ & $\begin{array}{l}\text { The indicators are adapted to Russian } \\
\text { reality }\end{array}$ & \\
\hline $\begin{array}{l}\text { Shahovskaya, L.S. (2015) / As- } \\
\text { sessment of regional intellectual } \\
\text { capital }\end{array}$ & $\begin{array}{l}\text { This method provides the most com- } \\
\text { plete picture of the state of human } \\
\text { capital }\end{array}$ & $\begin{array}{l}\text { 1. The final indicator is similar to the Human De- } \\
\text { velopment Index, which can result in a confusion } \\
\text { of concepts and goals; } \\
\text { 2. More focus is placed on human capital than } \\
\text { on other indicators, which may lead to biased } \\
\text { estimates }\end{array}$ \\
\hline $\begin{array}{l}\text { Kireeva, V.V. (2015) / Aggregate } \\
\text { assessment of the intellectual } \\
\text { capital of regions }\end{array}$ & Easy to calculate; availability of data & $\begin{array}{l}\text { 1. The structural capital of the region is repre- } \\
\text { sented by only one indicator; } \\
\text { 2. The indicators of human and social capital } \\
\text { reflect the state of the human capital and require } \\
\text { clarification of the indicators of social capital }\end{array}$ \\
\hline $\begin{array}{l}\text { Kuyantseva, I.I., Kuyantse- } \\
\text { va, M.I. (2011) / Regional } \\
\text { intellectual capital index }\end{array}$ & $\begin{array}{l}\text { ted indicators are not } \\
\text { o the structure of regional } \\
\text { al capital }\end{array}$ & $\begin{array}{l}\text { The method is based on the minimum set of in- } \\
\text { dicators, which fail to provide a complete picture } \\
\text { of regional structural capital }\end{array}$ \\
\hline $\begin{array}{l}\text { Ermolaev, M.B., Ivanova, V.Yu. } \\
\text { (2012) / Assessment of regional } \\
\text { intellectual capital based on the } \\
\text { ideal point method }\end{array}$ & $\begin{array}{l}\text { 1. Absence of subjective evaluation } \\
\text { when weighting the indicators; } \\
\text { 2. Selected indicators tested for } \\
\text { correlation }\end{array}$ & $\begin{array}{l}\text { This method is suitable for rating assessment, but } \\
\text { it is difficult to draw conclusions when conside- } \\
\text { ring regional intellectual capital of individual } \\
\text { regions }\end{array}$ \\
\hline $\begin{array}{l}\text { Viedma Marti Jose Maria } \\
\text { (2011) / Region's Intellectual } \\
\text { Capital Benchmarking System }\end{array}$ & $\begin{array}{l}\text { This method can be used not only } \\
\text { for assessment, but also for strategic } \\
\text { management of intellectual capital }\end{array}$ & $\begin{array}{l}\text { The system of indicators covers a wide range } \\
\text { of socio-economic indicators, which leads to } \\
\text { blurring of the boundaries of the concepts under } \\
\text { discussion. }\end{array}$ \\
\hline $\begin{array}{l}\text { Hervas-Oliver, J.L., Dalmau-Por- } \\
\text { ta, J.I. (2007) / Regional index } \\
\text { of intellectual capital (macro-, } \\
\text { meso- and micro-levels) }\end{array}$ & $\begin{array}{l}\text { 1. The index and indicators, adjusted } \\
\text { to specific countries and to the vision } \\
\text { of territorial stakeholders. } \\
\text { 2. All aspects of intellectual capital } \\
\text { formation can be taken into account }\end{array}$ & $\begin{array}{l}\text { 1. The measurement system is complex and } \\
\text { multi-factorial, which requires a lot of time and } \\
\text { effort to carry out the assessment. } \\
\text { 2. Can contribute to the "double counting" effect } \\
\text { when considering some factors }\end{array}$ \\
\hline
\end{tabular}


Thus, we can conclude that there is currently no universal approach to the problem. In particular, this applies to the balance of indicators and reasonable equivalence or unequal importance of structural components. It should also be noted that none of the approaches we considered can be used to describe the formation and usage of intellectual capital as a fundamental resource for regional innovation development due to certain peculiarities of intellectual capital management. It is, therefore, necessary to consider the interactions of intellectual capital's structural components.

This study describes an approach that has certain advantages (although it does not eliminate all the disadvantages of the methods described above): first, it allows us to evaluate each structural component separately; second, relative indicators are used for evaluation, which enables us to conduct a more accurate comparison of the regions in question; and, finally, this method allows us to look at the balance of structural components.

\section{Method and Data}

The proposed approach includes an assessment algorithm. It can also be used to devise a step-by-step guide to effective decision-making. This approach takes into account the patterns of transformation of intellectual capital and is based on the principles of discreteness, accuracy, comprehensibility and effectiveness as well as the massive involvement of experts in this sphere in the research (see Figure 1).

The algorithm comprises five consecutive steps:

The first step is to identify the structural components of intellectual capital and the conditions of their functioning on the regional level. Since these processes are inextricably linked with the actions taken by the authorities to regulate innovation, we need to analyze the key principles of the regional innovation policy. We also need to identify specific problems associated with the formation and interaction of structural components.

Second, it is necessary to assess the current state of the structural components. To this end, we need to identify a set of indicators characterizing each structural component and to develop a model for quantitative assessment of each component and their comparison.

The third step is to assess intellectual capital by developing a mathematical model reflecting the balance of structural components and quantitative estimates of intellectual capital calculated at the previous step and interpret the results.

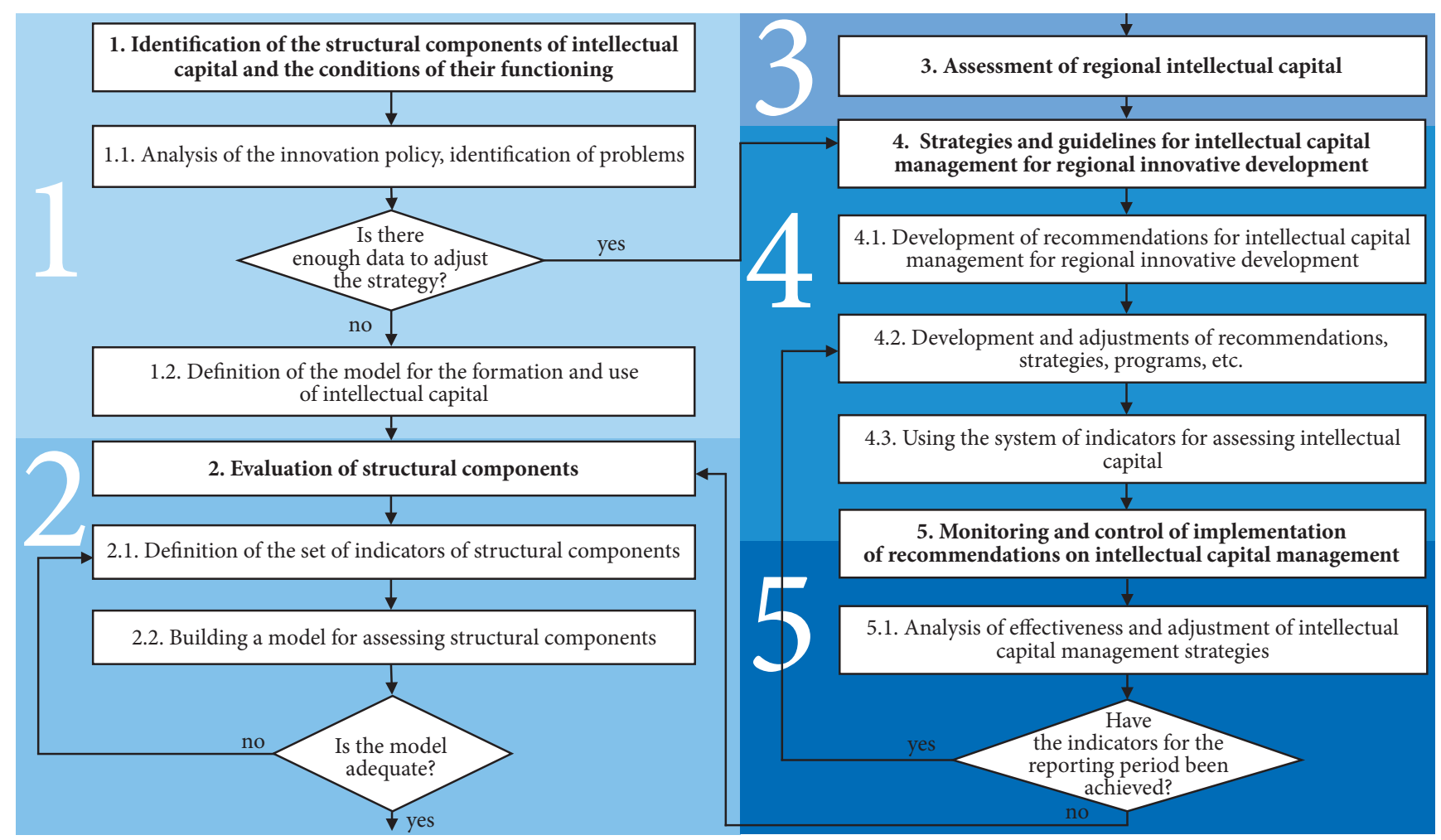

Figure 1. Algorithm for assessing the level of intellectual capital and the balance of its structural components for regional innovation development

Source: developed by the author 
Fifth, the data obtained at the previous step should be used to determine one of the alternative strategies of intellectual capital management and to devise methodological guidelines to improve the balance of its structural components. Importantly, the proposed system of indicators for assessing intellectual capital should be used by governmental bodies at the municipal and regional levels.

Finally, it is necessary to monitor the implementation of the proposed guidelines. If the goals are not achieved, it is necessary to return to Step 3 - "Assessment of structural components". If the goals are achieved, which means that the stra- tegy is effective, it is recommended to adjust the recommendations for intellectual capital management, program documents, and state programs in accordance with the results obtained.

To describe structural components of intellectual capital it is proposed to use sets of indicators, which are summarized in a consolidated indicator calculated as the arithmetic weighted mean of the corresponding indicators (Table 2). We selected the indicators by using previous research findings and by analyzing the key characteristics of structural components. Our choice also meets the requirements of minimum essential sufficiency, information availability, univer-

Indicators for components of regional intellectual capital

\begin{tabular}{|c|c|c|c|c|}
\hline Код & Indicator & Description & $\begin{array}{l}\text { Boundaries after } \\
\text { data normalization }\end{array}$ & Weight \\
\hline 1 & 2 & 3 & & 4 \\
\hline \multicolumn{5}{|c|}{ Structural capital } \\
\hline SC1 & $\begin{array}{l}\text { Advanced production technologies per } \\
10,000 \text { people }\end{array}$ & $\begin{array}{l}\text { Reflects the state of the regional } \\
\text { informational and technical infra- } \\
\text { structure for codification of available } \\
\text { knowledge }\end{array}$ & $\begin{array}{l}\text { Max value }=1 \\
\text { Min value }=0\end{array}$ & 0.33 \\
\hline SC2 & $\begin{array}{l}\text { Number of employees of governmental bodies } \\
\text { and local self-government per } 10,000 \text { people }\end{array}$ & $\begin{array}{l}\text { Reflects the state of the administra- } \\
\text { tive and organizational management } \\
\text { structure of the region }\end{array}$ & $\begin{array}{l}\text { Max value }=1 \\
\text { Min value }=0\end{array}$ & 0.17 \\
\hline SC3 & $\begin{array}{l}\text { Coefficient of inventive activity: the number } \\
\text { of applications for patents for inventions } \\
\text { and utility models filed per } 10,000 \text { people }\end{array}$ & $\begin{array}{l}\text { The coefficient reflects the level of } \\
\text { demand for protection of intellectual } \\
\text { property in the region }\end{array}$ & $\begin{array}{l}\text { Max value }=0 \\
\text { Min value }=1\end{array}$ & 0.5 \\
\hline \multicolumn{5}{|c|}{ Human capital } \\
\hline $\mathrm{HC} 1$ & Life expectancy & Reflects the overall quality of life & $\begin{array}{l}\text { Max value }=1 \\
\text { Min value }=0\end{array}$ & 0.2 \\
\hline $\mathrm{HC} 2$ & Dynamics of the number of researchers & $\begin{array}{l}\text { Reflects the quality of the region's } \\
\text { R\&D personnel }\end{array}$ & $\begin{array}{l}\text { Max value }=1 \\
\text { Min value }=0\end{array}$ & 0.33 \\
\hline HC3 & $\begin{array}{l}\text { Number of students enrolled in educational } \\
\text { programs of higher education - Bachelor's, } \\
\text { Specialist and Master's programs per } \\
10,000 \text { people }\end{array}$ & $\begin{array}{l}\text { Reflects the end result of the general } \\
\text { education system in the region }\end{array}$ & $\begin{array}{l}\text { Max value }=1 \\
\text { Min value }=0\end{array}$ & 0.2 \\
\hline $\mathrm{HC} 4$ & $\begin{array}{l}\text { Percentage of the population with monetary } \\
\text { income below the minimum standard of } \\
\text { living in this region }\end{array}$ & $\begin{array}{l}\text { Reflects the level of poverty and } \\
\text { inequality in the region }\end{array}$ & $\begin{array}{l}\text { Max value }=0 \\
\text { Min value }=1\end{array}$ & 0.13 \\
\hline HC5 & Migration rate per 10,000 people & $\begin{array}{l}\text { Reflects the region's attractiveness for } \\
\text { workers }\end{array}$ & $\begin{array}{l}\text { Max value }=1 \\
\text { Min value }=0\end{array}$ & 0.14 \\
\hline \multicolumn{5}{|c|}{ Relational capital } \\
\hline $\mathrm{RC} 1$ & $\begin{array}{l}\text { Share of expenditures on socio-cultural } \\
\text { events in the total expenditures of the re- } \\
\text { gional consolidated budget }\end{array}$ & $\begin{array}{l}\text { Reflects the availability of resources } \\
\text { to build trust with the local pop- } \\
\text { ulation through support of social } \\
\text { services and public infrastructure }\end{array}$ & $\begin{array}{l}\text { Max value }=1 \\
\text { Min value }=0\end{array}$ & 0.5 \\
\hline $\mathrm{RC} 2$ & $\begin{array}{l}\text { Number of small businesses per } 10,000 \\
\text { population }\end{array}$ & $\begin{array}{l}\text { Reflects how favorable the conditions } \\
\text { in the region are for doing business } \\
\text { and building relationships between } \\
\text { the government and local businesses }\end{array}$ & $\begin{array}{l}\text { Max value }=1 \\
\text { Min value }=0\end{array}$ & 0.17 \\
\hline RC3 & Export & $\begin{array}{l}\text { Reflects the efficiency of internation- } \\
\text { al economic relations }\end{array}$ & $\begin{aligned} \text { Max value } & =1 \\
\text { Min value } & =0\end{aligned}$ & 0.33 \\
\hline
\end{tabular}

Source: developed by the author. Based on the data from: Annual Statistical Collections of Rosstat "Regions of Russia. Socio-economic indicators” for 2000-2019, Federal State Statistics Service. Retrieved from https://www.gks.ru/ 
sality, and comparability. Each set of indicators includes both qualitative and quantitative indicators. However, there are difficulties of finding comparable information characterizing structural components, in particular, the relational capital (see Table 2).

The weighting factors of significance are determined by the method of paired comparisons. This method is a helpful tool in situations where only the preference relation between two indicators in a pair is available. To determine the preference of specific indicators to others, we used expert assessments. Since all the indicators have different dimensions, a linear scaling method (minimax method) was used in order to bring them to a comparable form.

The consolidated indicator of structural capital reflects the state of the intangible innovation infrastructure in a region, the indicator of human capital; the state of the system of human resources (e.g. attractiveness of living conditions for highly qualified workers); the indicator of attitude capital - the state of the system of internal (society - government - business) and external economic, political and socio-economic relations.

To measure intellectual capital it is proposed to use the method of volumes, namely, the calculation of the volume of a rectangular parallelepiped, which is formed along the axes XYZ, characterized by the levels of structural components (Figure 2).

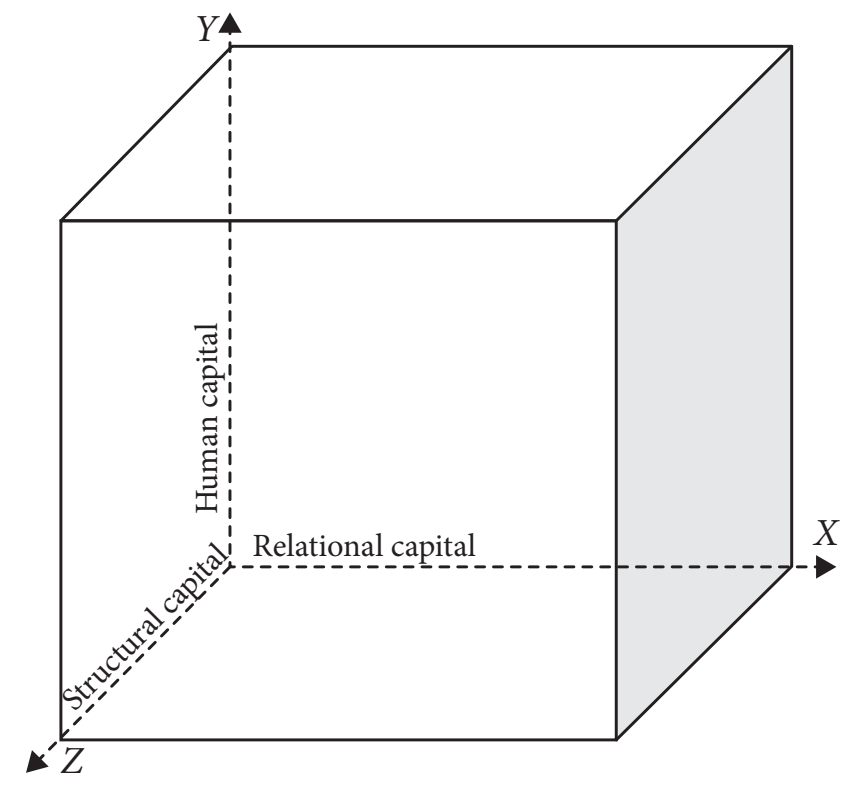

Figure 2. Assessment of regional intellectual capital through the volume method

Source: developed by the author
This method was chosen for the following reasons. Previous research findings have shown that it is impossible to build an objective qualitative regressing model describing the impact of structural components on innovation in regions due to the limited time periods for which intellectual indicators are usually calculated. Another reason is the lack of a single methodological approach to the calculation of such indicators, which increases the risks of duplication and inconsistency of data.

The choice of the multiplicative convolution method is determined by the fact that, firstly, the calculation of the volume of a rectangular parallelepiped reflects the level based on the values of human, structural and relational capital, and secondly, it does not require normalization of particular criteria, since it is assumed that they are of equal importance.

In this case regional intellectual capital is understood as a value that characterizes the development of regional intellectual capital as a product of multiplication indicators of its structural components.

To calculate the volume of the resulting figure, we applied the following formula:

$$
V=a \times b \times c
$$

where $V$ is regional intellectual capital or ICr, in fractions of one; $a$ is the consolidated index of regional human capital or HC, in fractions of one; $b$ is the consolidated index of regional structural capital, or SC, in fractions of one; $c$ is the consolidated index of regional relational capital or RC, in fractions of one.

Thus, the formula takes the following form:

$$
I C_{r}=H C \times S C \times R C .
$$

The formula allows us to calculate intellectual capital of each region under consideration and to analyze the results obtained both in the context of dynamics and in the context of geospatial assessment of how intellectual capital is formed and used in Russia.

Since for our calculations we used normalized data, the maximum and minimum limits of the value range can be defined as 1 and 0 , respectively.

Gradations and the corresponding numerical values of regional intellectual capital can be determined by using the Jenks natural breaks classification method, which is a method of clustering data to identify the best arrangement of values in different classes (Chen, J. \& Yang, S. \& Li, H. \& Zhang, B. \& Lv, J., 2013). Thus, the criteria for measurement of intellectual capital are as follows: 
1. High level of intellectual capital - the value of the calculated indicator lies in the range of 0.101 and above.

2. The average level of intellectual capital the value of the calculated index lies in the range $[0,059 ; 0,101]$.

3. Low level of intellectual capital - the value of the calculated index lies in the range from 0.059 and below.

However, as shown by the available research evidence, the nature of intellectual capital formation is not so much additive as synergetic in nature, which means that it should be assessed not only through the addition of individual parts, but also through the analysis of their interaction. Therefore, for a more accurate assessment, the criterion of balanced interaction of structural components is introduced.

To this end, we need to clarify the concept of balanced interaction of intellectual capital's structural components. It is worth noting that the concept of balanced interaction differs from the concept of effective activity, based on the principles of minimizing costs and maximizing effects. Balanced interaction is based on the principle of effects harmonization, depending on the importance of each structural element. In this case, the balance is the optimal combination of structural components, which provides the best result, and interaction is the process of direct or indirect impact of structural elements on each other, which results in their interdependence. Given this, the balance of structural components (or their balanced interaction) in this study will be understood as the result of their relationships, revealing the weight of their influence on innovative development.

The results of our empirical analysis of the distribution of the actual values of the calculated data have shown that the interaction of components can be considered balanced if at least one of the following conditions is met:

1) the consolidated index of human capital lies in the range of 0.45 to 0.6 ;

2) the consolidated index of the structural capital lies within the range of 0.3 to 0.5 ;

3 ) the consolidated index of the attitude capital lies within the range from 0.08 to 0.3 .

To determine whether the calculated value falls within the established ranges, it should be considered to a hundredth of a unit, since the established ranges are closed. Thus, the criterion scale of the balance of structural components will look as follows (see Table 3).
Table 3

\section{Criterion scale of the balance of structural components}

\begin{tabular}{|l|c|c|c|c|c|c|c|c|}
\hline $\begin{array}{c}\text { Structural } \\
\text { components }\end{array}$ & $\begin{array}{c}\text { Condi- } \\
\text { tions }\end{array}$ & \multicolumn{6}{|c|}{$\begin{array}{c}\text { Options for fulfilling the } \\
\text { conditions }\end{array}$} \\
\hline Human capital & $0.45-0.6$ & + & + & + & & + & & \\
\hline Structural capital & $0.3-0.5$ & + & + & & + & & + & \\
\hline Relational capital & $0.08-0.25$ & + & & + & + & & & + \\
\hline Balanced interaction & High & Medium & \multicolumn{3}{|c|}{ Low } \\
\hline
\end{tabular}

When none of the conditions are met, the interaction of structural components can be characterized as unbalanced.

Calculations of the consolidated indicators of structural components were made on the basis of data for 2000 to 2019.

It is important to note that some regions were excluded from the calculations due to the lack of statistical data for earlier time periods, including: the Nenets Autonomous District, the Republic of Altai, the Republic of Crimea, the federal city of Sevastopol, the Chechen Republic, the Republic of Tyva, the Republic of Khakassia, the Chukotka Autonomous District, the Republic of Ingushetia, and the Republic of Kalmykia. Thus, further analysis was carried out on the basis of data from 72 Russian regions.

Visualization of the obtained data was carried out by using the GeoDA software spatial modeling, which allows us to automatically group geo-objects on the basis of the natural boundaries criterion. The results of visualization are presented in the format of thermal maps of the Russian Federation, except for the above-mentioned regions.

\section{Results}

When considering heat maps, it is important to note the following: the grouping is based on the criterion of natural breaks and the number of intervals is set at 10, but the upper and lower limits of the intervals differ depending on the maximum and minimum values of the consolidated indicators for each period. Thus, for each year under consideration, 10 groups are formed from the lowest indicator value to the highest one.

Figure 3 shows heat maps of the consolidated indicators of human capital for Russian regions for several periods of time. Similar maps are also drawn for the values of the summary indices of structural and relational capital. 

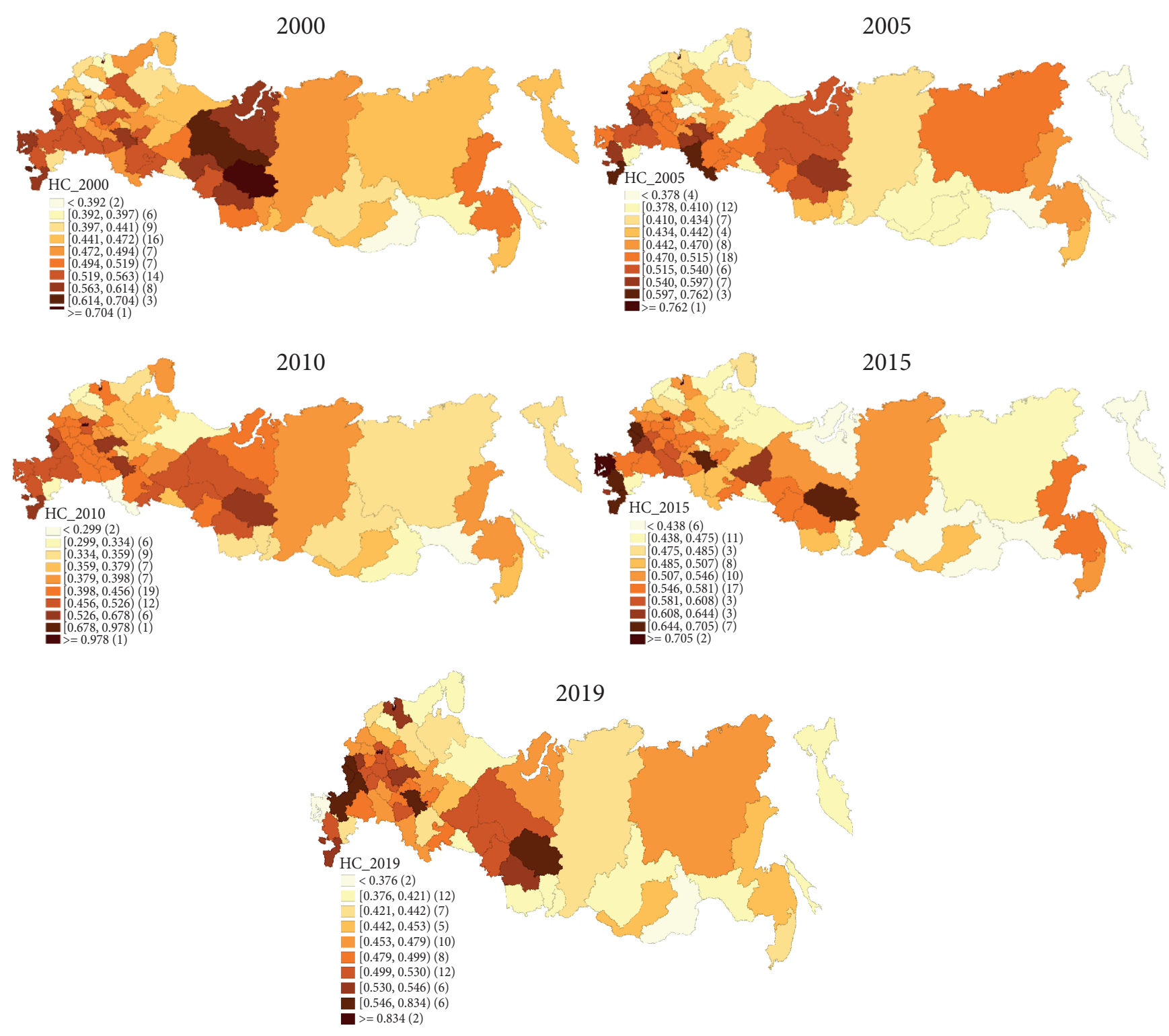

Figure 3. Heat maps of consolidated human capital indicators of Russian regions in 2000, 2005, 2010, 2015, and 2019

Source: developed by the author

If we look at the distribution of the values of the human capital indicator in Russian regions within a period covering several years, we can see how the polarization trend has been replaced by a more even distribution of human capital. In addition, we can note that in Russia as a whole, this indicator has not increased for 20 years.

Heat maps of structural capital indicators show that in the given period, the overall level of structural capital in Russia has slightly increased, especially compared to 2010 and 2015. However, in general, the picture looks very static, which can be explained by the reduction in the government spending on research and the reorganization of the federal executive authorities in charge of education and science (Figure 4).

Furthermore, due to the acceleration of digitalization, there is a growing amount of digital content and codified knowledge left uncovered by the methodology of the federal statistical bodies or official statistical data.

The heat maps of relational capital indicators show the most unstable picture, especially in 2015, when the average indicator of relational capital in Russia reached the highest levels. This can be attributed to the growing significance of the import substitution policy: in this period the Russian economy received a strong impetus to create 
export-oriented small businesses and strengthen horizontal ties (Figure 5).

Figure 6 shows the maximum and minimum values of the indicators corresponding to structural components of intellectual capital in a 20-year period, which allows us to trace the changes in the structure of intellectual capital. The dynamics of human capital is illustrated with a more uneven graph, both for maximum and minimum values. This can be explained by the particular nature of human capital stemming from the change of generations and the constant renewal of labor resources. The peak was recorded in 2010 at the level of 0.978 (Moscow). Similarly, the Russian capital has shown the record
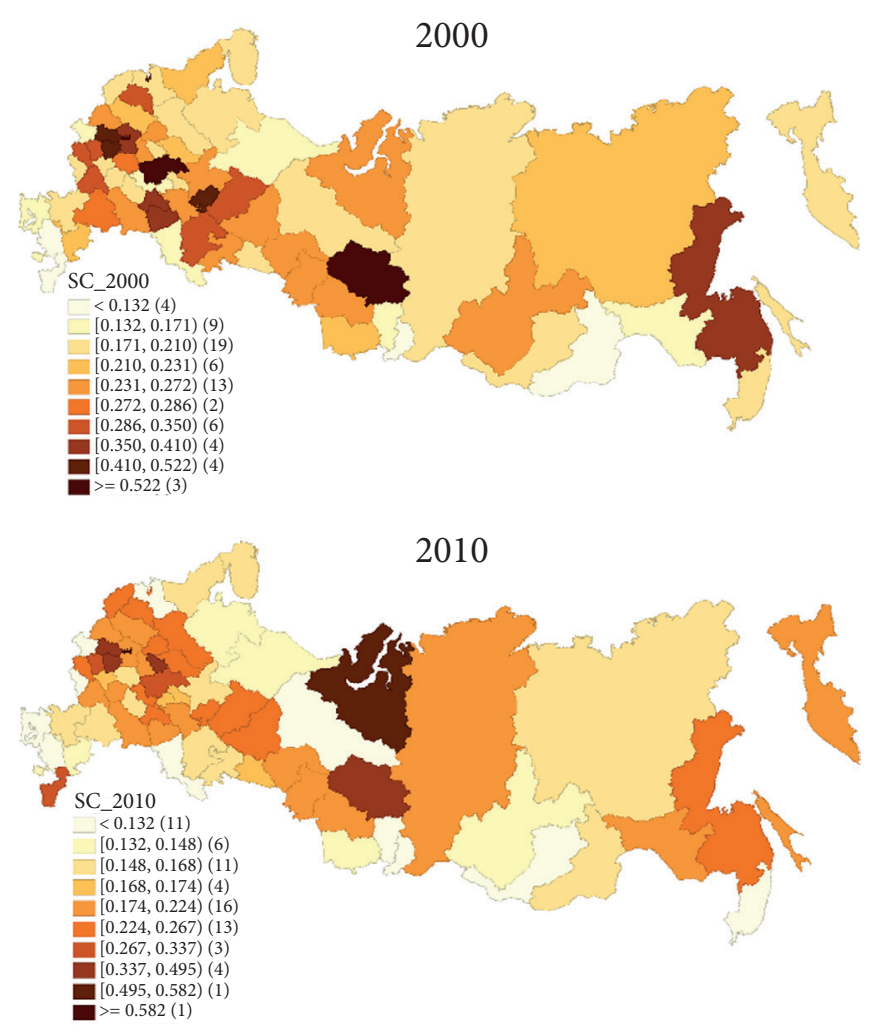

values of relational capital in 2018 at 0.916 . The minimum value of the human capital indicator was recorded in 2007 at 0.178 in Amur region.

The indicator of structural capital was the most stable: the line of the graph shows almost no sharp declines or peaks and remained at approximately the same level for almost 10 years. This can be explained by the fact that, unlike human capital, structural capital is easier to codify; thus knowledge and technology are not only preserved but also transferred to the next generations. The maximum value was recorded at 0.822 in 2019 in the Yamalo-Nenets Autonomous District; the minimum, at 0.019 in 2019 in the Republic of Dagestan.

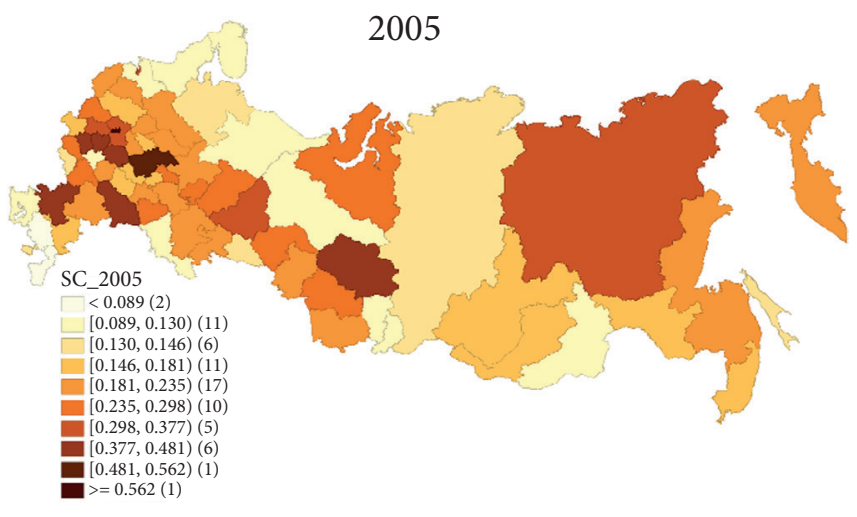

2015

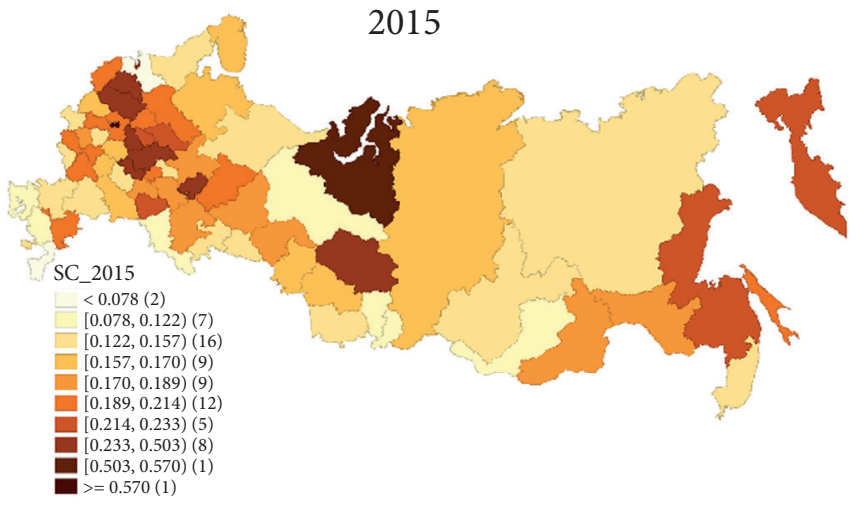

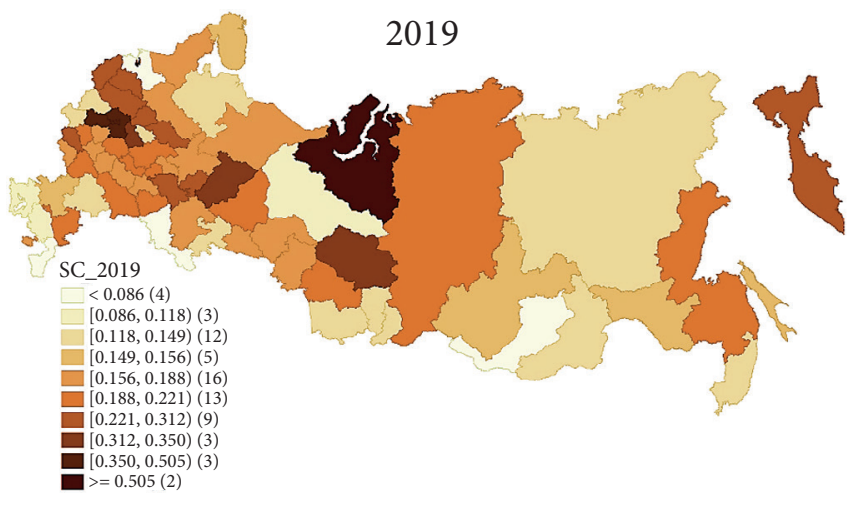

Figure 4. Heat maps of consolidated structural capital indicators of Russian regions in 2000, 2005, 2010, 2015, and 2019

Source: developed by the author 

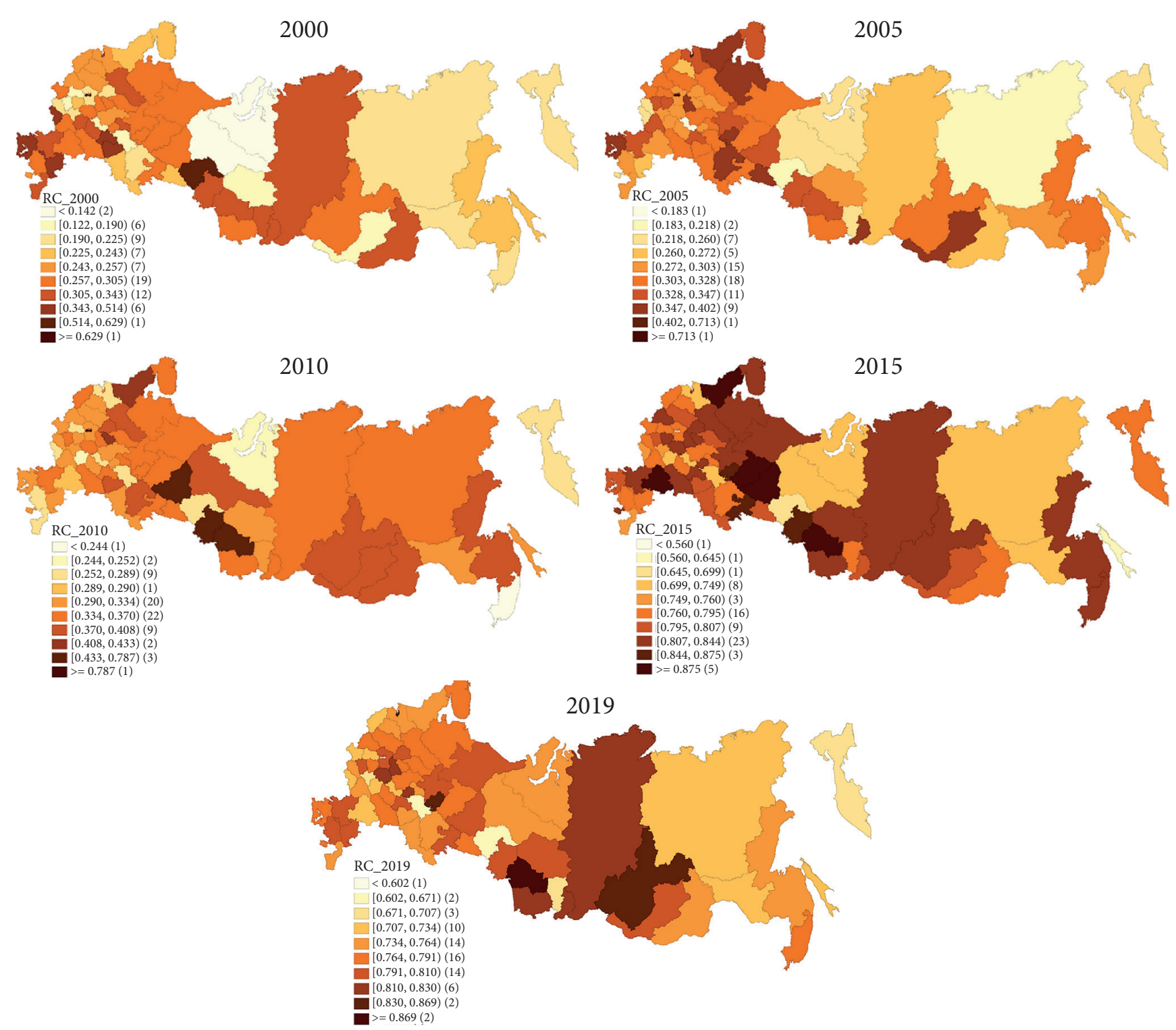

Figure 5. Heat maps of consolidated relational capital indicators of Russian regions in 2000, 2005, 2010, 2015, and 2019

Source: developed by the author

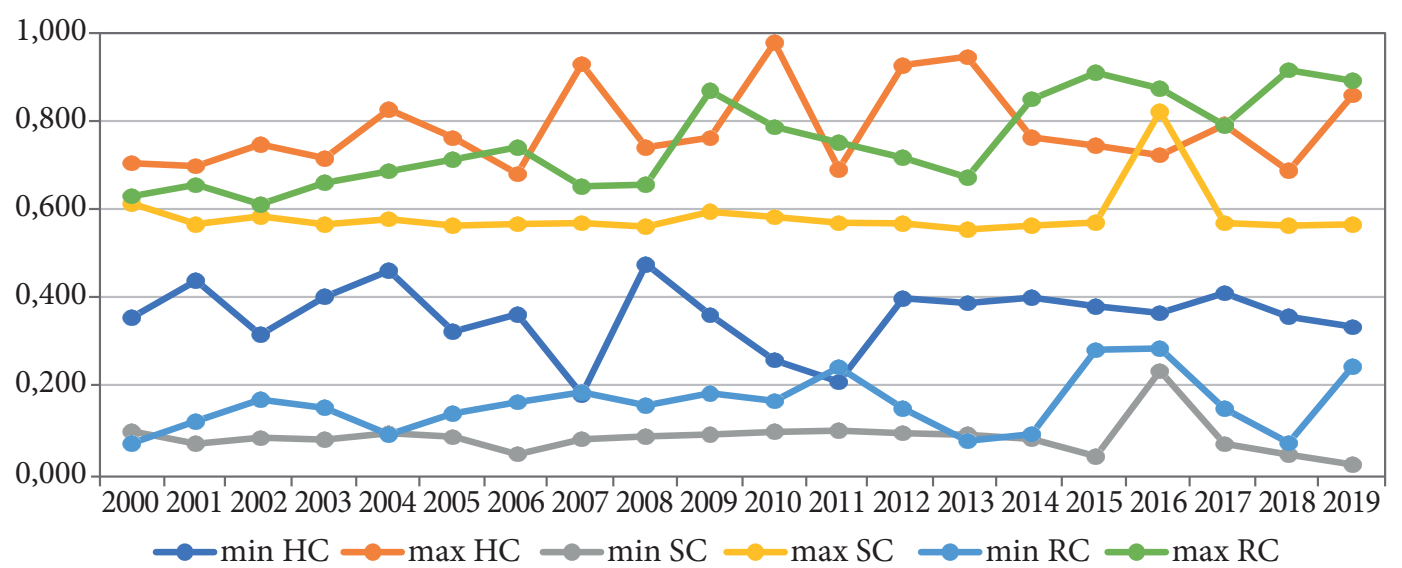

Figure 6. Maximum and minimum values of consolidated indicators of the intellectual capital's structural components in Russian regions in 2000-2019

Source: developed by the author 
The indicators of relational capital, unlike the indicators of structural and human capital, have an upward trend. The graph of the maximum values of relational capital has a jump-like form, and the graph of the minimum values has a smoothed form. Similar graphs reflecting the dynamics of human and structural capital indicators are more synchronous. This may be a confirmation of the fact that a high level of relational capital accumulation has a short-term self-growth effect. The maximum value of the consolidated indicator of relative capital was recorded in 2018 in Moscow, the minimum, in the Khanty-Mansi Autonomous District in 2000.

We conducted a data normalization procedure, which is why the extreme upper limit equals one. Therefore, the calculated values can be used to compare the consolidated indicators of components with each other.
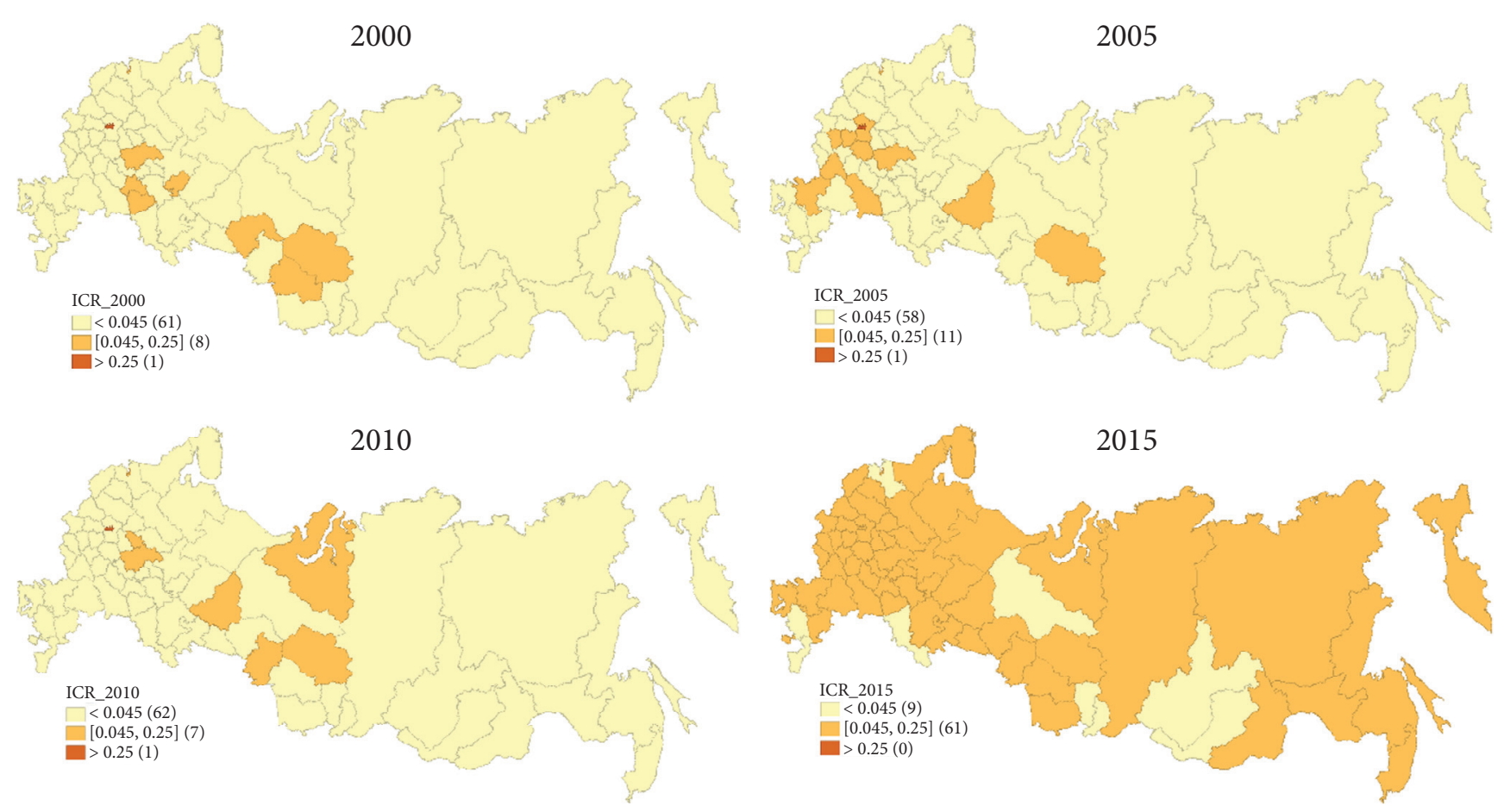

2019

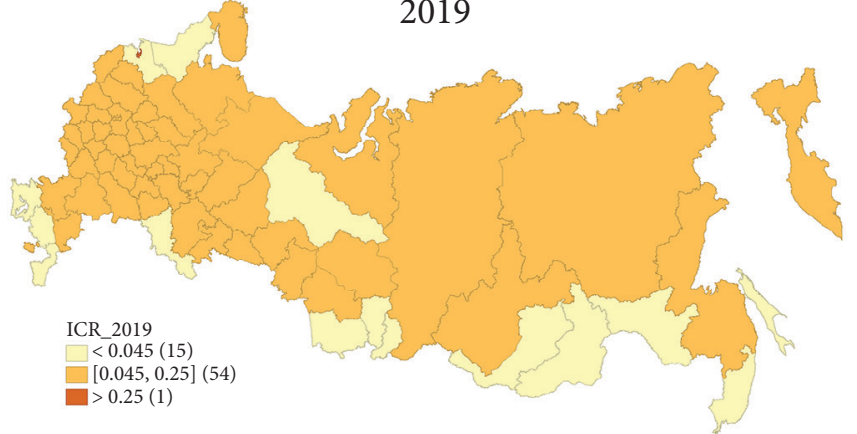

Figure 7. Heat maps of Russian regions' intellectual capital in 2000, 2005, 2010, 2015 and 2019 Source: developed by the author

The heat maps showing the level of regional intellectual capital in different periods are in $\mathrm{Fi}$ gure 7 . To group the regions, we chose the criteria corresponding to those mentioned above for assessing the level of intellectual capital.

Heat maps of intellectual capital within a period covering several years show the overall picture of formation and use of intellectual capital in Russia. These maps also help us assess the strength of the influence of its structural components on the final result. For example, in 2015 we can observe an abnormally high level of intellectual capital in 61 out of 72 regions. However, if we recall a similar heat map of the indicators of relational capital in 2015, we will see that they are synchronized. In other words, these maps show the effect of significant geopolitical events, such as the annexation of the Crimea in 2014, the international response and import substitu-

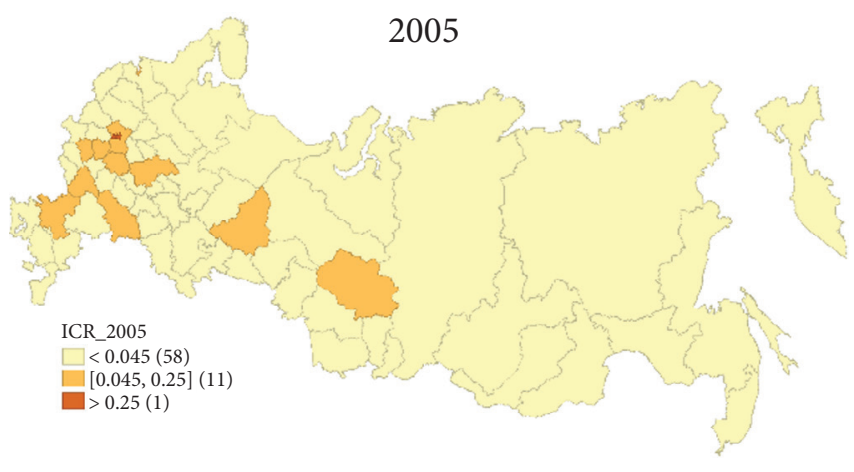

2015 
tion policy. All these events resulted in the mobilization of the country's own resources, reflected in the indicators of relational capital.

In general, in the given period, we can see an increase in the number of regions with a medium and high level of intellectual capital compared to 2005.

Figure 8 shows the dynamics of changes in the maximum and minimum values of intellectual capital in a 20 -year period. The graph that shows the maximum values of intellectual capital has high declines and peaks, but in general it illustrates an upward trend. The graph that shows the minimum values, on the contrary, is smoothed and has a downward trend in the short term. This may indicate the presence of a certain minimum viable level of intellectual capital in Russia.

The maximum value of intellectual capital was recorded in 2010 at 0.448 (Moscow), the minimum, in 2007 at 0.005 in the Trans-Baikal Territory.

Figure 9 shows the results of assessing the balance of structural components of intellectual capital in Russian regions in 2000, 2005, 2010, 2015 and 2019.
Assessment of the balance of structural components of intellectual capital show that the number of regions with a medium or high balance has almost halved. In the whole country, the balance has decreased, but at the same time, the polarization of values has almost disappeared.

If we examine each region separately, it is possible to identify certain patterns. However, a noticeable disparity in the way changes in different structural components influence the overall situation (the prevalence of human and structural capital) means that it is necessary to develop specific recommendations for intellectual capital management, taking into account the conditions in each particular socio-economic regional system.

According to the data for 2019, only 7 regions have a medium balance (one of which is not represented in the heat map) - Vladimir, Kaliningrad, Kaluga, Tomsk, Moscow, and Perm regions as well as the Yamalo-Nenets Autonomous District.
1 - high balance;
0.5 - medium balance;
0 - low or no balance.

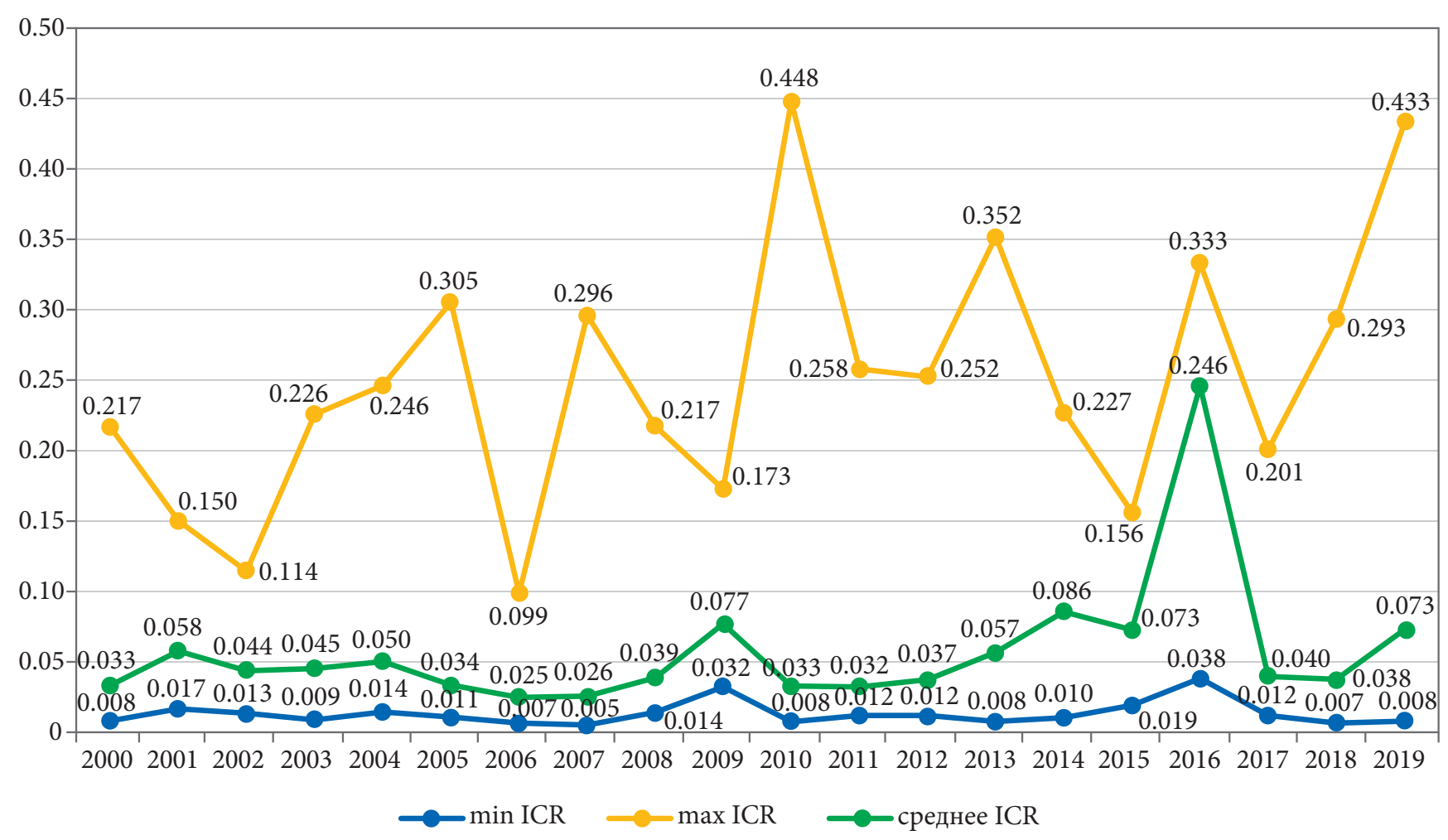

Figure 8. Maximum, medium and minimum values of Russian regions' intellectual capital in 2000-2019

Source: developed by the author 

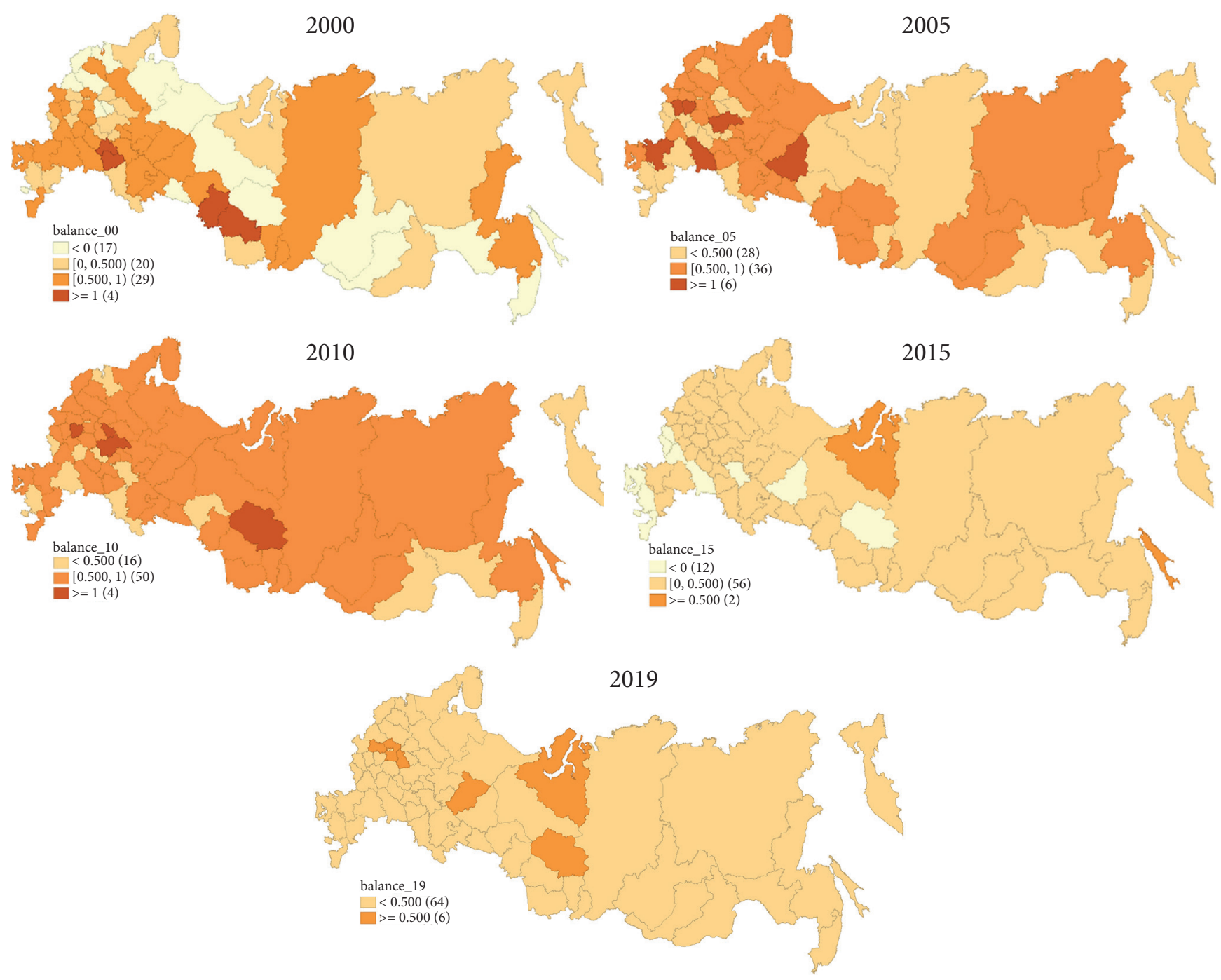

Figure 9. Heat maps of the balance of structural components of Russian regions' intellectual capital in 2000, 2005, 2010, 2015, 2019

Source: developed by the author

\section{Conclusion}

The proposed approach to assessing the balance of structural components of intellectual capital and its role in regional innovative development is based on an algorithm, a system of indicators, an evaluation model, and a criterion scale. This approach can be used to develop more effective management solutions. To assess the structural components of intellectual capital, sets of indicators are used and the corresponding consolidated indicators are calculated. Human capital contributes the most to a change in the index of intellectual capital in most regions. Moreover, in some cases, human capital in this major role may be replaced by relational capital in the way similar to the technical substitution of production factors.
The proposed approach is based on certain assumption. It also has a number of limitations, namely, we had to select indicators for specific structural components from a limited number of indicators calculated by Rosstat since 2000 in the framework of regional statistics. The quality and quantity of indicators that characterize the formation and use of intellectual capital, however, has increased significantly in recent years, giving us a certain freedom of choice. As far as the indicators calculated for 2015-2016 are concerned, we cannot conduct a retrospective analysis or build regression models.

Another limitation is the need to exclude some of the regions due to the lack of statistical data for the time period under review. Neverthe- 
less, the proposed approach allows us to assess the level of intellectual capital and the balance of structural components in Russian regions. We can also determine the system-forming component, which can serve as a basis for decision-making related to the adjustment of innovation policies at the regional level.

The results of our calculations for 72 Russian regions in a 20-year period lead us to the following conclusions:

1. The values of human capital indicators have a jump-like dynamics, in other words, in successive periods of time there can be recessions and peaks. Since it is primarily human capital that plays the key role in regional intellectual capital, this fact should be taken into account to evaluate the level of intellectual capital.

2. Values of structural capital indicators have smooth dynamics, which makes structural capital the most "stable" component of intellectual capital and makes the model of intellectual capital based on structural capital more relevant.

3. In the context of significant geopolitical and socio-economic events, relational capital has a stronger influence on capital than human or structural capital.

4. Intellectual capital and the balance of its structural components depends on how efficient is the management of intangible resources in re- gional innovation policies (such resources include human resources, organizational and administrative resources, and so on).

5. Our findings show that there are roughly three scenarios of the use of intellectual capital.

The first scenario implies that the region's potential for strategic development is fully realized and the balanced development of territories is ensured. New approaches to management are implemented through effective use of human capital at a sufficiently high level. As a result, this region realizes its innovative potential through the availability of highly qualified personnel, an effective education system, good demographic performance and an effective social protection system.

The second scenario implies that a region has a developed organizational infrastructure, both public and innovative, which gives an impetus to accumulation of human capital and relational capital.

The third scenario describes a situation where none of the structural components can be developed enough in mid-term, which means that none of them can act as a growth driver for the others.

The proposed approach can be used by governmental bodies to develop strategies for intellectual capital management and can be adjusted for other countries and regions.

\section{References}

1. Alkhateeb, A.N.A., Yao, L., \& Cheng, J.K. (2018). Review of Intellectual Capital Components Research. Journal of Advanced Social Research, 8(6), 1-14. Retrieved from http://www.sign-ific-ance. co.uk/index.php/JASR/article/view/1737

2. Andriessen, D. (2008). The Intellectual Capital of the European Union 2008: Measuring the Lisbon Strategy for Growth and Jobs. Electronic Journal of Knowledge Management, 7(4), 489-500.

3. Bontis, N. (2004). National intellectual capital index: a United Nations initiative for the Arab region. Journal of Intellectual Capital, 5(1), 13-39. doi: $\underline{10.1108 / 14691930410512905}$

4. Chen, J., Yang, S.T., Li, H.W., Zhang, B., \& Lv, J.R. (2013). Research on Geographical Environment Unit Division Based on the Method of Natural Breaks (Jenks). ISPRS - International Archives of the Photogrammetry, Remote Sensing and Spatial Information Sciences. XL-4/W3. 47-50. doi: 10.5194/isprsarchives-XL-4-W3-47-2013

5. Chub, A.A., \& Makarov P.Yu. (2015). Intellectual capital as a factor of sustainable development of Russian regions. Strategii biznesa: analiz, prognoz, upravlenie = Business strategies: analysis, forecast, management, 6(14). Retrieved from https://cyberleninka.ru/article/n/intellektualnyy-kapital-kak-faktor-ustoychivogo-razvitiya-regionov-rossii (In Russ.)

6. Barilenko V.I. (ed.) (2019). Complex analysis of economic activity: a textbook and a practical course for academic undergraduate studies. Moscow: Yurayt. 455 p. (In Russ.)

7. Ermolaev, M.B., \& Ivanova V.Yu. (2012). Method of integral assessment of the intellectual capital of the regions. Collection of scientific papers of Russian universities "Problems of economics, finance and production management", 31, 180-184. (In Russ.) 
8. Hervas-Oliver, J.L. Dalmau-Porta J.I. (2007). Which IC components explain national IC stocks? Journal of Intellectual Capital, 8(3), 444-469. doi: 10.1108/14691930710774867

9. Khuzina, N.Sh. (2015, November). Features of the assessment of the intellectual capital of an innovation-oriented enterprise. In N.S. Ishmukhametov (ed.) Paper presented at the VII All-Russian Scientific and Practical Conference with international participation Modern economy: theoretical and practical approaches (Ufa), (pp. 36-39), Ufa: RIC BashSU. (In Russ.)

10. Kireeva, V.V. (2015). Evaluation of intellectual capital as a factor in the development of the region. Volnoe ekonomicheskoe obshchestvo Rossii = Free Economic Society of Russia, 2(191), 239-254. (In Russ.)

11. Kuyantseva, I.I. \& Kuyantseva, M.I. (2011). Evaluation of the intellectual capital of the region. Prostranstvo ekonomiki = Economic space, 3. Retrieved from http://cyberleninka.ru/article/n/ otsenka-intellektualnogo-kapitala-regiona (In Russ.)

12. Kuzminykh, N.A., Mashkina, D.I., \& Roze, N.Sh. (2019). Assessment of the intellectual capital market efficiency. The European Proceedings of Social \& Behavioural Sciences, 8(85), 751-757. doi: $\underline{10.15405 / \text { epsbs.2019.03.02.85 }}$

13. Mačerinskas, J., \& Aleknavičiùtè R. (2012, June). National intellectual capital in Europe. Paper presented at the Proceedings of the Jubilee $X$ International Scientic Conference «Management and Engineering'12», Scientic Proceedings: Conference Proceedings (Sozopol, Bulgaria), Technical University Soa, Faculty of Management (pp. 763-771).

14. Makarov, P.Yu. (2015). Management of intellectual capital in the region. Moscow: RIOR; INFRA-M. 152 p. (In Russ.)

15. Maryam, H.J. et al. (2021). Intellectual Capital Components and its relationship to Microfinance institution's performance. International Journal of Business Research, 6(2), 69-80.

16. Naydenova, Yu., \& Oskolkova, M. (2012). Interaction between Intellectual Capital Components in Firm's Value Creation Process. Korporativnie finansi = Journal of Corporate Finance Research, 6(4), 100-112. (In Russ.) doi: 10.17323/j.jcfr.2073-0438.6.4.2012.100-112

17. Pap, E., Petković, M., \& Simićević, A. (2021). Measuring distribution of intellectual capital components contribution: French context. The European Journal of Applied Economics, 18(1), 1-14. doi: $10.5937 /$ EJAE18-28628

18. Pasher, E. (2005). The intellectual capital of state of Israel. In Bounfour, A., \& Edvinsson, L. (Eds) Intellectual Capital for Communities. Nations, Regions and Cities. Elsevier Butterworth-Heinemann, Burlington, MA. (pp. 139-150). doi: 10.1016/B978-0-7506-7773-8.50012-1

19. Pomeda, J. (2002). Towards an intellectual capital report of Madrid: new insights and developments. Paper presented at The Transparent Enterprise. The Value of Intangibles (Madrid, 25-26 November).

20. Rembe, A. (1999). The Governmental Invest in Sweden Agency-ISA: Report 1999. AB, Stockholm: Halls Offset AB

21. Roze, N.S. (2018) Structural and functional model of intellectual capital at micro-, mesoand macro-level]. Paper presented at the XII International Conference Russian regions in the focus of changes (Yekaterinburg, Russia), (pp. 31-46), Federal State Educational Institution UrFU named after the first President of Russia B.N. Yeltsin, Publishing House of UMC UPI. (In Russ.)

22. Roze, N.Sh. (2018). Model of effective interaction of structural components of intellectual capital at the regional level. Ekonomika $i$ upravlenie: nauchno-prakticheskij zhurnal = Economics and Management: a Scientific and Practical Journal, 1, 46-51. (In Russ.)

23. Shahovskaya, L.S. (2015). Evaluation of the intellectual capital of the region. Regionalnaya ekonomika. Yug Rossii = Regional economy: South of Russia, 3(9), 36-43. (In Russ.)

24. Smedlund, A. (2005). Intellectual capital creation in regions: a knowledge system approach. In Bounfour, A., \& Edvinsson, L. (Eds) Intellectual Capital for Communities. Nations, Regions and Cities, Elsevier Butterworth-Heinemann, Burlington, MA. (pp. 227-252). doi: 10.1016/B978-0-75067773-8.50017-0

25. Ståhle, P. (2005). Intellectual capital and national competitiveness: a critical examination. Case Finland Paper presented at the 6th European Conference of Knowledge Management (ECKM), University of Limerick (Limerick). 
26. Tovstiga, G., \& Tulugurova, E. (2009). Intellectual capital practices: A four-region comparative study. Journal of Intellectual Capital, 10(1), 70-80. doi: 10.1108/14691930910922905

27. Tumyan, L.V. (2015). Comparative analysis of the national intellectual capital of the participating countries of the Eurasian Economic Union. Kreativnaya ekonomika = Journal of Corporate Finance Research, 9(9), 1061-1082. (In Russ.) doi: 10.18334/ce.9.9.1926

28. Viedma Marti Jose Maria (2005). Cities' Intellectual Capital Benchmarking System (CICBS): A Methodology and a Framework for Measuring and Managing Intellectual Capital of Cities: A Practical Application in the City of Mataro. In Bounfour, A., \& Edvinsson, L. (Eds) Intellectual Capital for Communities. Nations, Regions and Cities, Elsevier Butterworth-Heinemann, Burlington, MA. (pp. 317-336). doi: 10.1016/B978-0-7506-7773-8.50022-4

29. Weziak, D. (2007). Measurement of national intellectual capital: application to EU countries. IRISS Working Paper Series. INSEAD, (Lifferdange November).

\section{Information about the author}

Nelly Sh. Roze - PhD student, Institute of Economics, Finance and Business, Bashkir State University (3/4, Karl Marx St., Ufa, Bashkortostan, 450076, Russian Federation); e-mail: nellliona@yandex.ru

ARTICLE INFO: received December 18, 2020; accepted April 29, 2021

\section{Информация об авторе}

Розе Нелли Шамилевна - соискатель, Институт экономики, финансов и бизнеса, Башкирский государственный университет (Россия, 450076, Уфа, ул. Карла Маркса, 3/4); e-mail: nellliona@yandex.ru

ИНФОРМАЦИЯ О СТАТЬЕ: дата поступления 18 декабря 2020 г.; дата принятия к печати 29 апреля 2021 г. 